\title{
Follicular Lymphoma Rich in Warthin-Finkeldey Cells
}

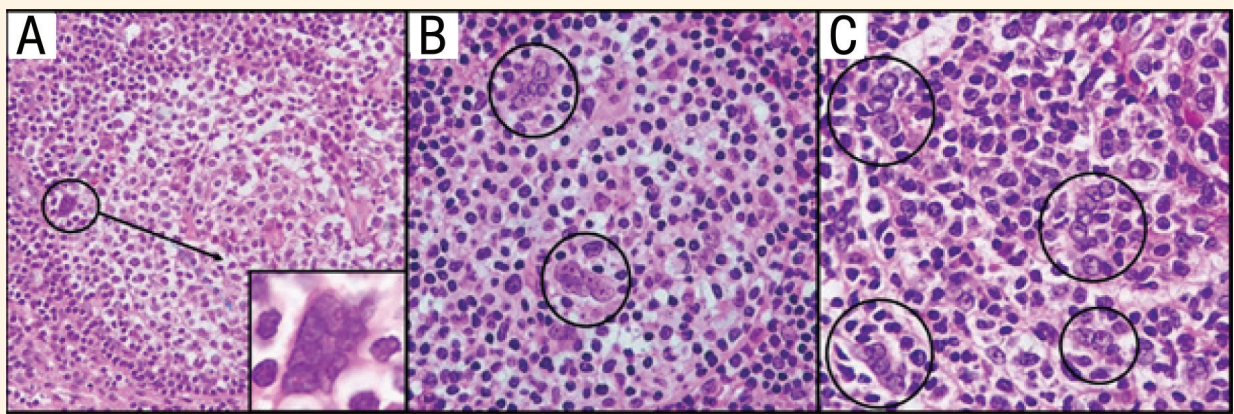

Figure 1: Haematolxylin and eosin stains at $(\mathrm{A}) \times 200$ magnification (low-power view; inset at $\times 1,000$ magnification) and (B \& C) $\times 600$ magnification (high-power views) showing neoplastic follicles that are predominantly composed of small cleaved cells and lack tingible-body macrophages, characteristic of follicular lymphoma. The presence of peripherally and centrally located Warthin-Finkeldey cells should be noted (black circles).

\section{A} 7O-YEAR OLD MALE PATIENT PRESENTED TO a tertiary care hospital in Amman, Jordan, in 2020 complaining of generalised lymphadenopathy in the neck, axilla and groin. There were no B symptoms, focal signs of infection or palpable spleen. Serologic tests for viral hepatitis and HIV were negative and the serum lactate dehydrogenase level was normal. The patient underwent excisional biopsy of cervical lymph nodes. Microscopic examination revealed effacement of the architecture by myriads of variable-sized follicles. The follicles were crowded, lacked the normal polarisation pattern and the presence of tingible-body macrophages and showed permeation of the lymph node capsule. The inter-follicular area was expanded by small cleaved lymphocytes. The follicles were composed of numerous centrocytes and a moderate amount of centroblasts [Figure 1]. An immunohistochemical study showed the follicles were positive for cluster of differentiation (CD)20, paired box (PAX)5, B-cell lymphoma (Bcl)2, Bcl6 and CD10. CD21 highlighted irregular follicular dendritic cell (FDC) meshwork inside the follicles. The overall features were diagnostic of grade-II follicular lymphoma. It should be noted that most of the neoplastic follicles exhibited one or more Warthin-Finkeldey cells (WFC). On low-power microscopic view, they appeared as dark, hyperchromatic cells, mainly located at the periphery of follicles and occasionally in the centre. The number of nuclei ranged from three to as many as 16 . The nuclei were round, larger than lymphocytes and exhibited vesicular chromatin and a small central nucleolus. They were arranged in grape- or chain-like patterns. Careful examination of PAX5 immunohistochemical staining showed a negative nuclear reaction in these cells [Figure 2].

\section{Comment}

WFC is a type of multinucleated giant cell that arises in lymphoid tissues in certain conditions. It was first described by Dr A. Warthin and Dr W. Finkeldey in 1931 after examining tonsils removed from children with measles. ${ }^{1,2}$ More studies revealed WFCs appearing in lymph nodes and even the appendix of measles patients, creating a strong relationship between them. ${ }^{3}$ However, later reports identified WFCs in various benign and malignant lymph node diseases such as HIV-lymphadenopathy, Kimura disease and neoplastic lymphoid proliferations such as Hodgkin lymphoma as well as B and T-cell lymphomas. ${ }^{4}$ WFC is characterised by a large size and numerous nuclei arranged in a grape-like cluster; the number of nuclei can be in the dozens. The cytoplasm and cell membrane are indistinct by light microscopy. The cells are mainly located in germinal centres, but can appear in interfollicular areas as well. The origin of WFCs remained enigmatic for decades, until it was recently found via immunohistochemistry that they express 


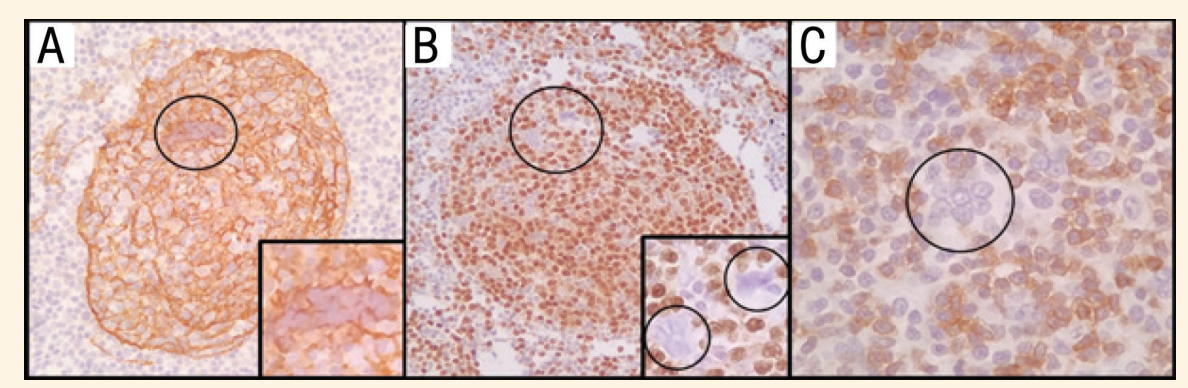

Figure 2: A: Cluster of differentiation (CD)21 immunohistochemical stain at $\times 200$ magnification showing follicular dendritic cells in the neoplastic follicle and the membranous positivity in Warthin-Finkeldey cell (WFC; inset at $\times 600$ magnification). B: PAX5 immunohistochemical stain at $\times 200$ magnification showing a positive result in the nuclear pattern in neoplastic lymphocytes but a negative result in WFCs (inset at $\times 400$ magnification). C: CD3 immunohistochemical stain at $\times 400$ magnification highlighting reactive T-lymphocytes but a negative result in WFCs. Black circles indicate the WFC.

FDC markers. ${ }^{5}$ While the pathogenesis of its formation is uncertain, it is hypothesised to result from the fusion of FDCs. ${ }^{5}$ This case brings to light the possible appearance of WFCs in follicular lymphoma which, to the best of the authors' knowledge, has not been previously described. This is an important massage to the community of pathologists as the presence of a follicular lesion in a lymph node with numerous WFCs does not indicate, by default, a reactive viral disease.

\section{AUTHORS' CONTRIBUTION}

TA conceptualised the work and established the diagnosis of the case. NB provided the image, conducted the literature review and drafted the manuscript. Both authors approved the final version of the manuscript.

\section{References}

1. Warthin AS. Occurrence of numerous large giant cells in the tonsils and pharyngeal mucosa in the prodromal stage of measles. Arch Pathol 1931; 11:864-74.

2. Finkeldey W. Ueber Riesenzellbefunde in den Guamenmandeln, zugleich ein Beitrag zur Histopathologie der Mandelveranderungen im Maserninkubationsstadium. Vichows Arch Pathol Anat $1931 ; 281: 323-9$.

3. Whalen TV, Klos JR, Kovalcik PJ, Cross GH. Measles and appendicitis. Am Surg 1980; 46(7):412-3.

4. Delsol G, Pradere M, Voigt JJ, Nespoulous M, Gorguet B, Marty $\mathrm{C}$, et al. Warthin-Finkeldey-like cells in benign and malignant lymphoid proliferations. Histopathology 1982; 6:451-65. https://doi.org/10.1111/j.1365-2559.1982.tb02742.x.

5. Orenstein JM. The Warthin-Kinkeldey-type giant cell in HIV infection, what is it? Ultrastruct Pathol 1998; 22:293-303. https://doi.org/10.3109/01913129809103350. 